\title{
Highlight report: predicting hepatotoxic oral doses of chemicals by in vitro testing and in silico modeling
}

\author{
Reham Hassan $^{1}$
}

Received: 15 July 2019 / Accepted: 18 July 2019 / Published online: 25 July 2019

c) Springer-Verlag GmbH Germany, part of Springer Nature 2019

Recently, a novel in vitro/in silico strategy has been published which allows the determination of oral doses of test compounds that cause an increased risk of hepatotoxicity (Albrecht et al. 2019). The novelty of this technique is that it is quantitative and allows differentiation of hepatotoxic and harmless dose ranges based on the results of an in vitro test.

A first step of this procedure is to determine the lowest concentration of a test compound that causes an adverse effect in an in vitro test battery ('alert concentration'). This test battery includes cytotoxicity and increased expression of a set of biomarker genes in cultures of cryopreserved human hepatocytes.

Next, this alert concentration is used to extrapolate to the lowest blood concentration $\left(C_{\max }\right)$ that causes an increased risk of hepatotoxicity in a human population. To allow this in vitro to in vivo extrapolation, the authors established a set of data with compounds, where the $C_{\max }$ in blood is known for a specific oral dose. Moreover, it is known, whether the $C_{\text {max }}$ of a specific compound increases the risk of hepatotoxicity or not. Based on this set of data the authors established the mathematical relationship between alert concentrations (in vitro) and the $C_{\max }$ in blood that causes an increased risk of hepatotoxicity. The alert concentrations in vitro are higher than the lowest $C_{\max }$ in blood that causes an increased risk of hepatotoxicity. Using the equation established by Albrecht et al. (2019) the alert concentration can now be used to calculate a $C_{\max }$ that causes an increased risk of hepatotoxicity in humans.

The third step is to determine the oral doses in repeated exposure scenarios that lead to the corresponding $C_{\max }$ (as determined in the previous step). This is achieved by reverse pharmacokinetic modeling. Depending on the availability

Reham Hassan

Reham_Hassan@vet.svu.edu.eg

1 Forensic Medicine and Toxicology Department, Faculty of Veterinary Medicine, South Valley University, Qena, Egypt and quality of physico-chemical and pharmacokinetic data this final step may still be associated with a certain degree of uncertainty.

Hepatotoxicity represents an active field of research (Sissung et al. 2019; Grinberg et al. 2014; Stöber 2016) and much effort has been invested to establish adequate in vitro and in silico methods (Grinberg et al. 2014, 2018; Godoy et al. 2016, 2018; Gu et al. 2018; Frey et al. 2014). However, hepatotoxicity in vivo represents a complex process (Ramachandran and Jaeschke 2019; Woolbright and Jaeschke 2018; Hammad et al. 2014, 2017). While hepatocytes often are the primary target (Ghallab et al. 2016, 2019; Leist et al. 2017) initial key events may also occur in cholangiocytes (Jansen et al. 2017; Vartak et al. 2016) or may be mediated by immune cells (Mossanen et al. 2016; Godoy et al. 2013; Reif et al. 2017). Therefore, predicting such complex processes by in vitro in silico methods it is a major challenge. The technique of Albrecht et al. (2019) has now been applied to 36 compounds and allowed surprisingly accurate predictions of hepatotoxic blood concentrations. It will be interesting to learn more about the accuracy of the method when a larger number of compounds will have been studied.

\section{Compliance with ethical standards}

Conflict of interest The author declares that she has no conflict of interest.

\section{References}

Albrecht W, Kappenberg F, Brecklinghaus T, Gardner I, Rahnenführer J, Hengstler JG et al (2019) Prediction of human drug-induced liver injury (DILI) in relation to oral doses and blood concentrations. Arch Toxicol 93:1609-1637. https://doi.org/10.1007/s0020 4-019-02492-9

Frey O, Misun PM, Fluri DA, Hengstler JG, Hierlemann A (2014) Reconfigurable microfluidic hanging drop network for 
multi-tissue interaction and analysis. Nat Commun 5:4250. https ://doi.org/10.1038/ncomms5250

Ghallab A, Cellière G, Henkel SG, Drasdo D, Gebhardt R, Hengstler JG et al (2016) Model-guided identification of a therapeutic strategy to reduce hyperammonemia in liver diseases. J Hepatol 64(4):860-871

Ghallab A, Hofmann U, Sezgin S, Jansen PLM, Hengstler JG, Reif $\mathrm{R}$ et al (2019) Bile Microinfarcts in cholestasis are initiated by rupture of the apical hepatocyte membrane and cause shunting of bile to sinusoidal blood. Hepatology 69(2):666-683. https://doi. org/10.1002/hep.30213

Godoy P, Hewitt NJ, Albrecht U et al (2013) Recent advances in 2D and $3 \mathrm{D}$ in vitro systems using primary hepatocytes, alternative hepatocyte sources and non-parenchymal liver cells and their use in investigating mechanisms of hepatotoxicity, cell signaling and ADME. Arch Toxicol 87(8):1315-1530

Godoy P, Widera A, Schmidt-Heck W, Blüthgen N, Dooley S, Hengstler JG et al (2016) Gene network activity in cultivated primary hepatocytes is highly similar to diseased mammalian liver tissue. Arch Toxicol 90(10):2513-2529

Godoy P, Schmidt-Heck W, Hellwig B, Nell P, Feuerborn D, Rahnenführer J, Kattler K, Walter J, Blüthgen N, Hengstler JG (2018) Assessment of stem cell differentiation based on genome-wide expression profiles. Philos Trans R Soc Lond B Biol Sci. https:// doi.org/10.1098/rstb.2017.0221

Grinberg M, Stöber RM, Edlund K, Leist M, Rahnenführer J, Hengstler JG et al (2014) Toxicogenomics directory of chemically exposed human hepatocytes. Arch Toxicol 88(12):2261-2287

Grinberg M, Stöber RM, Albrecht W, Ellinger-Ziegelbauer H, Rahnenführer J, Hengstler JG et al (2018) Toxicogenomics directory of rat hepatotoxicants in vivo and in cultivated hepatocytes. Arch Toxicol 92(12):3517-3533. https://doi.org/10.1007/s0020 4-018-2352-3

Gu X, Albrecht W, Edlund K, Han B, Hengstler JG, Stoeber R et al (2018) Relevance of the incubation period in cytotoxicity testing with primary human hepatocytes. Arch Toxicol 92(12):35053515. https://doi.org/10.1007/s00204-018-2302-0

Hammad S, Hoehme S, Friebel A, Gebhardt R, Drasdo D, Hengstler JG et al (2014) Protocols for staining of bile canalicular and sinusoidal networks of human, mouse and pig livers, three-dimensional reconstruction and quantification of tissue microarchitecture by image processing and analysis. Arch Toxicol 88(5):1161-1183

Hammad S, Braeuning A, Meyer C, Mohamed FEZA, Hengstler JG, Dooley S (2017) A frequent misinterpretation in current research on liver fibrosis: the vessel in the center of $\mathrm{CCl}_{4}$-induced pseudolobules is a portal vein. Arch Toxicol 91(11):3689-3692

Jansen PL, Ghallab A, Vartak N, Reif R, Schaap FG, Hampe J, Hengstler JG (2017) The ascending pathophysiology of cholestatic liver disease. Hepatology 65(2):722-738

Leist M, Ghallab A, Graepel R, Kroese D, van de Water B, Hengstler JG et al (2017) Adverse outcome pathways: opportunities, limitations and open questions. Arch Toxicol 91(11):3477-3505

Mossanen JC, Krenkel O, Ergen C, Roskams T, Trautwein C, Tacke F et al (2016) Chemokine (C-C motif) receptor 2-positive monocytes aggravate the early phase of acetaminophen-induced acute liver injury. Hepatology 64(5):1667-1682. https://doi. org/10.1002/hep.28682

Ramachandran A, Jaeschke H (2019) Acetaminophen hepatotoxicity. Semin Liver Dis 39(2):221-234. https://doi. org/10.1055/s-0039-1679919

Reif R, Ghallab A, Beattie L, Günther G, Kuepfer L, Kaye PM, Hengstler JG (2017) In vivo imaging of systemic transport and elimination of xenobiotics and endogenous molecules in mice. Arch Toxicol 91(3):1335-1352. https://doi.org/10.1007/s00204-016-1906-5

Sissung TM, Huang PA, Hauke RJ, McCrea EM, Peer CJ, Barbier RH, Strope JD, Ley AM, Zhang M, Hong JA, Venzon D, Jackson JP, Brouwer KR, Grohar P, Glod J, Widemann BC, Heller T, Schrump DS, Figg WD (2019) Severe hepatotoxicity of mithramycin therapy caused by altered expression of hepatocellular bile transporters. Mol Pharmacol 96(2):158-167. https://doi. org/10.1124/mol.118.114827

Stöber R (2016) Pathophysiology of cholestatic liver disease and its relevance for in vitro tests of hepatotoxicity. EXCLI J 15:870-871

Vartak N, Damle-Vartak A, Richter B, Dirsch O, Dahmen U, Hammad S, Hengstler JG (2016) Cholestasis-induced adaptive remodeling of interlobular bile ducts. Hepatology 63(3):951-964

Woolbright BL, Jaeschke H (2018) Mechanisms of inflammatory liver injury and drug-induced hepatotoxicity. Curr Pharmacol Rep 4(5):346-357. https://doi.org/10.1007/s40495-018-0147-0

Publisher's Note Springer Nature remains neutral with regard to jurisdictional claims in published maps and institutional affiliations. 